\title{
Medical Pluralism During and After Socialism: A Study of Psychotronics in the Former Czechoslovakia
}

\author{
Ivan Souček
}

DOI: 10.21104/CL.2020.1.03

\begin{abstract}
The paper starts with a discussion on the concept of medical pluralism, then presents a theoretical framework of the exclusive medical model, which recognizes only one legal system for medicine. The author then considers psychotronics activities as a specific form of alternative healthcare, along with describing and analysing the healthcare situation that existed during the socialist period in former Czechoslovakia and compares it with the contemporary pluralistic situation that emerged in both the Czech Republic and Slovakia. The findings of this paper suggest that, despite the prevalent rationalist view during the socialist period and the tendency to promote biomedicine as the only legitimate and superior healthcare practice, the conditions for the development of pluralism in medical healthcare were nevertheless created. The paper concludes that research on the shifting relationship between alternative medicine and mainstream medicine reveals how scientific objectification fluctuates, or at least is negotiable, under the influence of social circumstances.
\end{abstract}

\section{Key words}

psychotronics, socialist period, Czechoslovakia, alternative medicine, pluralism

\section{Acknowledgment}

This paper was prepared as part of the research project VEGA 1/0333/19 'Analysis of Selected Social Contexts of Using Alternative Forms of Healthcare in Slovakia'.

I would like to thank the two anonymous reviewers for their suggestions and comments on the manuscript.

\section{Contact}

Mgr. Ivan Souček, PhD., Department of Social Studies and Ethnology, Matej Bel University, Tajovského 40, 97401 Banská Bystrica, Slovakia; e-mail: ivan.soucek@umb.sk.

\section{Jak citovat / How to cite}

Souček, Ivan. (2020). Medical Pluralism During and After Socialism: A Study of Psychotronics in the Former Czechoslovakia. Český lid 107, 51-69. doi:http://dx.doi.org/10.21104/CL.2020.1.03 


\section{Introduction}

Several studies conducted in recent decades support the assumption that dissatisfaction with the dominant medical system eventually results in numerous alternative therapies (Sharma 1996; Spiegel et al. 1998; Sirious - Gick 2002). However, the existence of pluralism and the availability of diverse healthcare options are not entirely specific to modern society. According to Sarah Cant and Ursula Sharma (1999), in almost every period in time, there has been a choice of different kinds of healing methods. The situation has changed significantly over the last few decades and the modern form is characterized by a highly structured diversity. Therefore, it seems appropriate to refers to it as a 'new' medical pluralism (Cant - Sharma1999). Moreover, in the context of modern neo-liberal economies, non-biomedical healthcare products have become an object of commodification, while nonEuropean forms of medicine have been adapted for Western needs (Ross 2012). As the contemporary medical environment is characterized by a wide range of available diagnostic and therapeutic methods, some authors have continuously applied the concept of 'medical pluralism' (Kleinman 1980; Baer - Singer - Susser 2003; Johannessen - Lázár 2006). It was originally introduced by Charles M. Leslie $(1976 ; 1980)$, who was the first anthropologist to apply it to a study of South Asian societies in order to highlight its various connotations. At a global level, Leslie claimed that medical pluralism was a noticeable part of every system of healthcare throughout the world, with every therapeutic system failing to help many patients. Leslie further pointed out that every medical system has its limitations, which lead consumers to search for alternative possibilities to solve their problems. In turn, different therapeutic traditions offer diverse meanings and potentials for those who suffer from health concerns. Discontent with medical care is then interpreted as a significant force that stimulates the existence of a pluralistic medical environment.

\section{Medical pluralism reconsidered: the case of Eastern Europe}

However, over the years, the concept of medical pluralism, as well as the significance of patients' discontent, has been criticized for several reasons. For instance, according to Elisabeth Hsu (2008), due to neglecting the patients' perspective, generating a false consciousness of choice or reproducing a monolithic concept of (bio-)medicine, the concept is unsatisfactory and does not reflect social theories. Moreover, as Paul Brodwin (1996) argues, it seems that both the contribution made by the concept at a theoretical level and its application are problematic. Meanwhile, the concept often stands behind the production of rigid and functionalist ty- 
pologies of the medical environment. It means that even despite the common assumption that medical pluralism manifests itself differently, taking many various forms, while being affected by different political and social histories, many of the typologies employed incomparable characteristics. For instance, Murray Last (1996) outlines three main types of regulatory systems, which can help to determine, in a political sense, the nature of the medical culture in any state: namely, exclusive, tolerant and integrated. Last argues that the former Soviet Union represents a prototypical example of an exclusive system. ${ }^{1}$ For a long time, there was only one legally recognized system of medicine in contrast to traditional or folk medicine, which, according to a positivistic worldview, comprised irrational practices arising out of a misunderstanding of science. This attitude began to manifest itself in a significant way with the onset of the Soviet Union's Cultural Revolution in 1928, which launched the wholesale modernization of society with contemporary, secular and Soviet values at its core. Every kind of folk healing method became the target of a propaganda campaign, drawing attention to the superstitious and anti-scientific character of such techniques (Michaels 2003). Many other former socialistoriented countries in Central and Eastern Europe intelligibly followed the Soviet approach. Further, it is supposed that the medical domain in postsocialist countries in Europe went through a phase in which the healthcare environment was rapidly controlled, followed by a gradual release that led to a partial equalization of various medical practices (Ong et al. 2005). On this matter, Jan Stepan points out that in 'the socialist countries of Eastern Europe, where the health professions have as a rule become integrated into the public services, health care is provided virtually exclusively on the basis of modern medicine' (Stepan 1985). Such conclusion, however, raises certain fundamental questions. First of all, was the Soviet system really so exclusive? Did the socialist countries in Europe unconditionally adopt the Soviet attitude toward the alternative forms of healthcare? If the answer is negative, then what approaches prevailed in these countries and how could the medical environment be characterized there? And is the discussion on medical pluralism distinctively relevant in this part of the world? Or is it necessary to call for a reformulation of the concept? Last but not least, to what extent has the past shaped the present-day situation? In order to acquire a better understanding of these issues it is necessary to clarify the intention of this article.

1 Besides this model, the author distinguishes two more medical monopolies, French and American, which are characterized by centralized state control restricting the existence of any non-conventional healing practices provided by healers. 
As the concept of medical pluralism has, over recent decades, been thoroughly examined and its contribution to the understanding of multiple medical realities is seemingly exhausted, it would be more convenient to go beyond the notion of medical pluralism as the mere coexistence of different medical options and deal with more specific issues forming the plural environment in the medical area. Given the existence of psychotronics researchers and their wide-ranging activities in Czechoslovakia, this article seeks to demonstrate that the medical environment had a heterogeneous character and, moreover, that the medical monopoly of biomedicine was far from unconditional. The analysis concentrates on particular strategies developed by psychotronics representatives, with specific reference to Czechoslovakia during the socialist period, in order to achieve wider acceptance and gain social power. By focusing on the institutional dimension of psychotronics in the former Czechoslovakia, the article tries to demonstrate how the existence of medical pluralism is embedded in the discourse of scientific/unscientific dichotomy. It tries to identify, through the development of a social institution and its representation, how the notion of pluralism in medical structure is shaped by the authority of science as a power structure. Thus, the paper compares the situation of healthcare during the socialist period in the former Czechoslovakia with the contemporary pluralistic situation that emerged in the Czech Republic and Slovakia after the regime change of 1989 . This change brought about various forms of complementary and alternative medicine (CAM).

\section{Data and methods}

It is widely acknowledged that the history of non-scientific medicine in Central and Eastern European countries is strongly associated with methods of traditional folk medicine and uses of herbal medicine (Nedelcheva - Draganov 2014; Penkala-Gawecka 1995; Horváthová 1987). Besides, there are numerous examples from medical anthropology showing that alternative healthcare modalities, whether at a theoretical or a practical level, are constituted by, and transformed through, broader social developments (Brosnan - Vuolanto - Brodin Danell 2018). Accordingly, this study regards psychotronics as a historical and social object and explores how and why the strategies of one alternative healthcare modality were constructed and changed. The decision to study psychotronics in the context of healthcare pluralism is twofold: first, the existence of other alternative healthcare modalities, with a few exceptions (Kř́žzová 2015; Stöckelová - Klepal 2018; Klepal - Stöckelová 2018), had a limited impact on the development of medical diversity during the socialist 
period; second, the fact that, as its specific therapeutic application was developed exclusively in former Czechoslovakia, it can be formally designated within the complementary and alternative medicine (CAM) phenomenon. This is immediately apparent when looking at relatively rich psychotronics literature published in the 1990s in the Czech Republic and Slovakia dealing with attempts to utilize the potential energy of the human organism to heal various kinds of anomalies in the energetic field of subjects (Rosinský 1991).

The following paragraphs are based on ethnographic fieldwork conducted between 2008 and 2016 among Slovak and Czech individuals who are commonly labelled as 'psychotronics'. Semi-structured interviews were conducted to investigate differences in their personal attitudes and insights. In order to systemize the data to accord with predefined topics of interest, standard techniques were used during analysis. Attention was specifically focused on how these practitioners define themselves, what kind of activities they deal with and what their understanding of psychotronics in the context of complementary and alternative medicine is. Considering that most published literature on the topic of history of psychotronics remains very poor and particular results of psychotronics research were not officially reported through the conventional scientific methods, further understanding of the past inevitably relies on narrative analysis. Recognizing the usefulness of oral storytelling, the research in selected cases used narrative ethnography for description and explication of interlocutors' perception of related topics in contextual features.

Despite the heterogeneous focus of psychotronics, it is often defined as a specific interdisciplinary field of research which deals with the investigation of interactions between living organisms and the environment (Belko 2000). The research hypothesis presupposes that psychotronics refers to individuals who are interested in the theoretical investigation of related phenomena as well as various practitioners with attributed extraordinary abilities falling under the phenomena of psychotronics. Due to this ambiguity, the following study integrates the insiders' perspective of self-identification and sharing of a collective identity with an external perception which attributes belonging to a particular social group according to its formal criteria. To ensure that the participants' identity is protected, it is anonymized. In addition, some of the data presented here stem from the analysis of interviews conducted during a four-year seminar programme and the annual two-day conference organized by the Slovak Psychotronics Society. The aim, amongst other things, was to investigate social processes contributing to the institutional organization of psychotronic representatives and the historical dynamics affecting the 
development of the subject. Most of the information regarding the history of the institutional background of psychotronics was obtained during this seminar. It was related to other available sources dealing with its historical development in Czechoslovakia, such as the published proceedings of its annual conference (available in a downloadable version from the website of the Slovak Psychotronics Society) and declassified documents held by US intelligence agencies. These documents have been approved for release in redacted versions and are available on the website of the Central Intelligence Agency under the domain called Stargate, which was a code name for a secret project established by the Defence Intelligence Agency to investigate the possible application of paranormal phenomena for military use. Despite their tendentious character, these documents display a high degree of proficiency and provide us considerable insights into historical development of psychotronics research in the socialist countries of Eastern Europe. Last but not least, in order to facilitate a comprehensive understanding of psychotronics activities within social contexts, related laws, reports and policy documents were also thoroughly studied.

\section{History of research into paranormal phenomena}

The beginning of a systematic interest in the investigation into paranormal phenomena can most probably be traced to 1882, when the Society for Psychical Research was established in England (Rao 2010). The activities of early protagonists concentrated on the study of telepathy, followed by hypnotism, apparitions and Reichenbach's Odic force. The importance of the society is confirmed by the fact that its existence prompted further activities of similar societies in other countries in Europe and the US. However, awareness of parapsychology was raised among the wider public after the foundation of the Parapsychology Laboratory at Duke University in 1927 and the publication of J. B. Rhine's book New Frontiers of the Mind (Berger - Berger 1991). This book, describing the research conducted at the Parapsychology Laboratory, such as psychokinesis or extrasensory perception, contributed to the popularization of the term parapsychology. In the following years, with the establishment of parapsychological experimental laboratories in various countries around the world, the objects of investigation became more diversified in accordance with local demands.

The history of parapsychological research in Russia goes back even further, to the pre-revolutionary period. After the culmination of interest throughout the 1930s, further research was forbidden. Several parapsychological phenomena began to be treated as vicious antisocial supersti- 
tions and threats that undermined the doctrine of materialism. Any attempt to study paranormal activities in the Soviet Union was, for many years, considered as idealism or religion. The official attitude toward psychotronics in the Soviet Union changed in the 1950s, when the legitimation of the discipline was prompted, to a considerable extent, by the Communist Party's recognition of other scientific branches, which had been previously rejected as bourgeois idealism. The Soviet interest in the paranormal reawakened due to its possible pragmatic use by the military on the one hand, and the shift in interpretation, on the other, in order to rebut materialistic attacks and align research with official scientific and political thoughts (Maire - LaMothe 1975). Psychotronics research in the Soviet Union was, thus, motivated by pragmatism and attempts to apply paranormal capabilities when carrying out certain tasks.

In principle, the research that was conducted in the West, some in France, some in Belgium, was badly financed. That's why the results were not so big. They did it the same way in America, even in the Soviet Union at that time. The research ran under the guise of the secret services or the military, and the results were published only after a long time. The Americans made considerable methodological mistakes, so there were not many results, and [research] was primarily focused on the issues of clairvoyance, better still, telepathy and telegnosis. In the Soviet Union, the research was richer, and it also involved medicine. But, because it was done by the Research Institute of Military Medicine and other affiliated institutes, it was all secret. (psychotronics practitioner 'T1', 2009)

Further, the term 'psychotronics' (in French: psychotroniques) was coined in 1955 by the French engineer Fernand Clerc to refer to a discipline that was supposed to be a successor to parapsychology, which was understood as the field involving the research of energetic and informational possibilities of the psychic aspects of living organisms. Clerc first used this term in the French radio-technological journal Toute la Radio, while discussing the existence of various phenomena without a common and unified name. The psychotronics discipline informed a substantial part of parapsychological research, expanding its area of interest to matter energy and, subsequently, on information phenomena. While the term 'psychotronics' first appeared in 1955, it never gained wide acceptance in Western European countries and the USA. On the other hand, the term became popularized in the former Soviet Union and Czechoslovakia dur- 
ing the 1970s, when scientists from the Soviet bloc researched psychotronics problems similar to those investigated by their colleagues in Western Europe and the USA (Belko 2000).

Generally, the psychotronics community has been seeking to investigate several occurrences relating to the interaction of beings with each other and their surroundings without the facilitation of known sense organs or verifiable forms of energy (Hamilton 1977). Basically, this pursuit has included phenomena such as telepathy, precognition, psychokinesis and energetic therapy. As discussed later in this paper, despite the use of different investigative approaches, Czechoslovakian researchers, in the field of the interaction of matter, energy and consciousness, considerably contributed to the development of medical applications and research into the possibilities of energy transfer via healing interventions and diagnosis, which were incompatible with biomedical scientific methods (Belko 2000). For instance, Czech researchers claimed that they successfully proved a direct transfer of energy from healthy to injured muscle (Hamilton 1977). As one respondent confirmed, while similar research activities were also being undertaken in other countries, the former Czechoslovakia was alone in placing an emphasis on medical applications:

This kind of research was conducted not only in our country. In Europe, there were some activities designed for diagnostic and therapeutic purposes. They evolved in a way that was apparently unrelated to other methods. However, it is clear that such a focus in psychotronics began in particular in Czechoslovakia, following the establishment of psychotronic research facilities that functioned in the 1970s and 1980s. (psychotronics practitioner 'T3', 2013)

\section{Expansion of psychotronics in Czechoslovakia during the socialist period}

Even in the inter-war period in former Czechoslovakia, several famous and well-known personalities were engaged in research on paranormal activities. One of them was Břetislav Kafka, author of the most popular book about parapsychology in the first half of the 20th century. Later, in the 1960 s, the first official reports on intensive experiments with parapsychological phenomena were prepared under the name of psychotronics. Czech scientist Zdeněk Rejdák adapted the new term in order to pursue a novel investigation into phenomena related to extraordinary and paranormal interactions between humans and other bodies and matter. In several Eastern European countries from the early 1970s onwards, psychotro- 
nics became an organized discipline, while a research group under the name 'Koordinační skupina pro výzkum otázek psychotroniky' (Coordination group for research on psychotronics issues) was established in 1967. The growing interest among scientists to study paranormal phenomena led, in 1973, to the organization of a unique conference, held in Prague. ${ }^{2}$ The conference was attended by more than 250 delegates from almost every country engaged in researching psychic phenomena at a significant level in order to discuss recent investigations in this field. The main idea behind the establishment of this meeting was to create a forum for the exchange of information and experience, thereby unifying the international community of scholars engaged in the interdisciplinary scientific research on, and development of, psychotronics. Among the participants were several scientists from the field of physics, psychology, psychiatry and medicine, who, in six working sections, discussed topics such as dowsing, telepathy, out-of-body travel and energetic healing. Several influential and renowned researchers, such as Július Krmešský and Robert Pavlita, promoted Czechoslovakian research advances. During the congress, on the initiative of Zdeněk Rejdák, the International Association for Psychotronic Research was established. This association took responsibility for the organization of subsequent international events (1975 in Paris, 1978 in Tokyo), which provided opportunities to exchange the latest news and ideas regarding psychotronics research (Rosinský - Synčák 2008). These events prompted a wave of interest in psychotronics research in former Czechoslovakia and consequently led to the demand for the establishment of a national research association focused on exploring interaction between mind and matter. Initially, in 1978, under the guidance of former Minister of Education František Kahuda, a Psychotronics Laboratory was founded at the Faculty of Electrical Engineering, Czech Technical University in Prague. Meanwhile, following the international congress held in Monte Carlo in 1980, the Research Centre for Psychotronics and Yuvenology at University of Chemistry and Technology in Prague was opened under the supervision of Z. Rejdák and conducted several research studies related to the interaction of living organisms without a presently identified energy mechanism (Belko 2000). Furthermore, applied research was focused on the possibilities to use energy transfer from one organism to another, in

2 The report, which contains proceedings of the first conference on psychotronics research, with articles examining various aspects of philosophical-psychological and technical-physical concepts for comprehending psychic phenomena, was released by the US Government and is available in a partial version on the following website: https://archive.org/details/JPRSL502226September1974ProceedingsOfTheFirstConferenceOnPsychotronicResearchPartII. [2019-01-30] 
order to reduce diseases. In June of 1983, the Fifth International Conference on Psychotronic Research took place in Bratislava. Approximately three hundred attendees in three sessions addressed a wide range of topics. One of the sections, 'Psychotronics and Medicine' focused on contributions dealing with psychotronics in the fields of therapy and diagnosis, such as psychic healing and iridology (Targ 1983). As no results or methods of research into the subject were officially published in an accessible journal, further details of their activities remain unknown to the public.

Due to the fact that Czechoslovakia was in the sphere of influence of the Soviet Union, several aspects of social, cultural and political life were subject to Soviet ideology; for example, this meant that every kind of research activity in the field of CAM was difficult to advance due to a lack of human and financial resources. However, despite criticism based on political ideology, psychotronics qualified for an exemption, likewise in the Soviet Union. As one informant pointed out, this was possible due to close ideological and political ties with the Soviet research community and the ambiguous nature of theoretical psychotronics principles:

At that time, we were, of course, under the influence of Russia and the Soviets. When we then needed some financial cover and support for the study of healing, but also for other psychotronics phenomena, we were able to see officials and say that such research was also being done in the Soviet Union. Suddenly it was possible. (...) It was secret, given the fact that no one was sure whether or not all these things were based on dialectical materialism. (psychotronics practitioner 'T1', 2009)

Psychotronics researchers in Czechoslovakia made several different attempts to establish materialistic and objectivist explanations for observed paranormal activities. In order to bring psychotronics research in line with science and widely accepted physical theories, researchers postulated the existence of a fifth fundamental force, as well as sought to formulate a unified theory to describe it. Moreover, they emphasized electrostatic or electromagnetic components of such energy, which played an important role in the determination of the natural character of unverified psychic phenomena. Officials were dealing with questions about whether a psychotronics discipline could be successfully developed into an academically acknowledged scientific method or whether it could be considered as a pseudoscientific approach without application. Within the activities of psychotronics representatives seeking to represent their research as an 
interdisciplinary study of remote interaction of living organisms using scientific terminology and a mainstream materialistic paradigm, we can identify efforts to gain increasing influence and social status. To this end, through attempts to institutionalize research and establish ideologically acceptable interpretations, which did not conflict with mainstream scientific criteria, psychotronics not only eliminated organized official attacks and criticism to a relatively successful degree, but even attracted statefunded research. Further research in Czechoslovakia, with a few exceptions, was thus conducted with government sponsorship. According to the informant, research programmes that received funding from government institutions were in a secure position in both a personal and a financial sense. The following statement from the informant explains the personal and technical conditions under which psychotronics research proceeded:

\begin{abstract}
The financial support was not negligible, things were technically well supported, as all the devices were quite costly. Most of the research staff were highly experienced and skilled, so that, from 1980 to 1982, there was an opportunity to launch official state research, of course in secret. (psychotronics practitioner 'T1', 2009)
\end{abstract}

Considering the status and possibilities for the development of psychotronics research, it is evident that the study on the energetical and informational interaction of living organisms enjoyed a golden age in Czechoslovakia during the socialist period. That said, researchers who were interested in further research made effective progress into the mid1990s, when the situation began to gradually change.

\title{
The position of psychotronics under the impact of new challenges
}

Unlike Western Europe, where we can see the re-emergence of alternative healthcare, together with a strong medical counterculture, at least since the mid-1960s, the situation in the Central and Eastern European region has been quite different. Saks (2005) highlights that, in the 1960s, in Western Europe and the USA, public attitudes changed toward traditional forms and ways of thinking, while a countercultural critique challenged rational progress and the superior role of biomedical practitioners. These trends among frustrated people played a significant role in the increasing interest in alternative medical practices. Meanwhile, in Eastern and Central European countries, which did experience the same, or at least similar, changes in society, the development of an alternative healthcare sector was completely different. The change occurred with the arrival of 
a new political establishment, and radical social and political changes that took place after the fall of the communist regimes. In 1989, the formation of pluralism, even in the area of healthcare, seemed possible. However, as we have already stated, it would be incorrect to claim that, before this date, there was no discussion about alternative medicine. Besides psychotronics, acupuncture, for instance, appeared in Czechoslovakia in the early 1960s and gained a relatively stable position in the 1970s, after its integration into the system of socialist healthcare, when the Ministry of Health issued the first decree defining the methodological guidelines for using acupuncture and established it in the law as an 'interdisciplinary method of medicine' (Stöckelová - Klepal 2018: 38).

In the initially liberal atmosphere, the development of plural healthcare environment was relatively tolerated by state officials, and it was not perceived as a problematic phenomenon. In fact, when the Psychoenergetic Laboratory, under the guidance of F. Kahuda, was terminated after the loss of state support for parapsychological research in 1993, it was taken over by the Czech Psychoenergetic Society. The year before, in Bratislava, the first hospital ward for acupuncture and natural medicine was opened, while a natural medicine ward was established at the University Hospital in Košice. By the mid-1990s, there had been a sharp turnaround in attitudes toward the practice of alternative medicine on the part of the state, academies of science and medical chambers. Following the dismissal of the main expert in natural medicine by the Minister of Health of Slovakia and the dissolution of the aforementioned natural medicine ward, the possibilities for medical research in this area were considerably limited. In the Czech Republic, the shift in perception was accompanied by intensive disputes between supporters and opponents of non-conventional forms of medicine, which ultimately led to a change in the law, which strictly prohibited healthcare practices that operated on the basis of licensed businesses. At the core of the escalating attack on alternative medicine was an ideological battle between scientific and nonevidence-based practices, in an attempt to prevent various non-conventional therapies from being covered by public health insurance. Following, in 1997 the acupuncture and homeopathy were excluded from health care insurance (Telec 2017). Despite various activities of CAM representatives to legitimize their activities, the issue of legal status in this area has remained unchanged until today. This means that, in contemporary Czech and Slovak society, the legal position surrounding healing has not been explicitly formulated; that is, its practice is neither forbidden nor authorized. Slovak law $^{3}$ regulates the activity of healers only indirectly

3 Act No. 576/2004 Coll. on health care and on services related to health care. 
by defining boundaries that cannot be exceeded. From the legal perspective in Slovakia and the Czech Republic, healers are individuals without specific rights or obligations (Kováč 2008; Kř́žová 2015). Furthermore, in Slovakia, healthcare is defined in the law as a set of occupational activities performed exclusively by healthcare workers (Souček - Hofreiter 2017). The law also defines who can be considered as a healthcare worker; healers are not included. Unlike healthcare practitioners, healers do not have to register themselves, nor are they required to hold any licence entitling them to perform medical services. Moreover, they have no obligation to be appropriately trained or prove their educational achievements. They also do not come under the control of the Healthcare Surveillance Authority or the Ministry of Health because they do not provide healthcare according to the law. A similar situation regarding the position and legitimacy of the healer profession is prevalent in the Czech Republic. However, among Czech healers, we can observe a greater tendency toward professionalizing the practice in terms of training and organization. In the Czech Republic, there is no umbrella organization that can oversee the overall performance of the healing profession, although the Czech Psychoenergetic Society does register dowsers and practitioners of various traditional and modern forms of non-conventional medicine. There is also a Czech-Moravian Union of Healing Arts, but it currently appears to be inactive. Individuals in Slovakia who are concerned about healing issues can contact the Slovak Psychotronics Society, which is a civil society body that aims to connect people with an interest in current advances in psychotronics research. A member of the society may be an adult citizen of either Slovakia or the Czech Republic, or even a Slovak or Czech living outside their home country. The society also organizes an annual twoday conference, where the latest research results, theoretical clarifications and papers from different disciplines impacting on psychotronics phenomena are presented. Furthermore, the society runs a four-year seminar programme, designed for interested people to gain a more detailed and systematic understanding of the theoretical foundations of energetic and information systems. Meanwhile, the Society for Natural Medicine runs accredited courses for doctors, organizes events for the professional community and publishes its own electronic magazine in Slovak and English. According to Gustáv Solár (2013), president of the society and a protagonist in the first clinic of acupuncture and natural medicine, the study of natural medicine is determined by energetic and informational processes (also referred to as energo-informational processes). Therefore, natural medicine focuses primarily on the study of these processes in an organism and in relation to health and illness. 
During the 1990s, extensive research activities were interrupted and state-funded support eliminated, which led to a gradual decline in psychotronics investigations, as confirmed by Teodor Rosinský, founder and chairman of the Slovak Psychotronics Society. In one of his published articles, he describes the contemporary situation: 'Current psychotronics suffers in the same way as many non-preferred areas of research - a lack of money and a lack of qualified people. Therefore, in our country, as elsewhere, we have had to focus on tasks that do not require expensive equipment, space and full-time employees. This has meant that we have only been able to work in a modest and amateur fashion, for the sake of knowledge, not profit' (2012: 2). Considering the liberalization and marketization of healthcare that took place after the regime change in 1989, we can presuppose that, among the reasons that contributed to weakening the status and impact of psychotronics, specific attention should be paid to the following: a more heterogeneous character of healthcare providers and the constitution of a strict binary opposition between conventional medicine and psychotronics. The change in the political system in 1989 not only affected the development of medical forms, which were already known and practised (albeit in a limited form), but also led to the growing popularity of medical elements, about which little had been previously known. For instance, in a relatively short time, homeopathy became one of the most popular methods of CAM in the Czech Republic as well as in Slovakia (Kř́žová 2015; Souček - Hofreiter 2017). Thus, while the impact of other alternative healthcare options was rather limited in the socialist period, and most of the efforts by the psychotronics community were concentrated on meeting the criteria of science and biomedicine, later on, the situation considerably changed. After the rise in the popularity of other non-conventional medical alternatives and the development of a heterogonous medical environment in the Czech Republic and Slovakia, as in other European countries, psychotronics was forced to cope with a highly competitive healthcare marketplace. Thus, in order to target a particular clientele, several variants of alternative medicine developed elaborate expansion strategies, reflecting the fact that clients had more freedom to choose the appropriate therapeutic approach for them. Under such circumstances, psychotronics became less competitive, which resulted in the abandonment of the relatively stable position it had built up during the socialist period. Paradoxically, a vigorously constructed image of the subject as a mainstream, scientific discipline could have led to the current decline of interest in its use, compared to some other alternatives which are gaining popularity fast due to the fact that they highlight strict opposition to biomedicine. In addition, in recent years, we can see, within 
this profession, both a buoyant tendency towards syncretisation and borrowing ideas and practices from different medical strategies, as well as the blending of new religious movements' tenets with alternative therapies:

In my practice, I rely on methods from traditional medicine and using herbs that I have collected myself. (...) The person is set like a puzzle. It must be understood that this puzzle has several levels. From the physical and then [there is] energy. (...) Above the uncontrolled levels are energetic pathways, meridians. These connect all the organs of the body. Over the tracks is the chakra system, and then there is information, that is why we came into being. (psychotronics practitioner 'S2', 2008)

Interestingly, despite the continuous attempts to professionalize the activity of psychotronics, enabling them to be taken seriously in society, the sceptics in Czech and Slovakia emphasizing materialistic viewpoints continue to be dismissive in their attitude, regarding alternative therapies as pseudoscience with no potential to contribute to medical research. Seeing that psychotronics represents part of the CAM phenomenon, according to major representatives of conventional medicine, it is considered, at best, to be ineffective or, worse still, potentially dangerous. The Czech Medical Chamber has even released a statement against the practice of various alternative methods of healing and expressed serious reservations about them. In the case of psychotronics, the chamber has made the following statement: 'Psychotronics assumes the possibility of transmitting psychic impulses to a sick person, and biotronics [assumes] the ability to emit "bioenergy" with healing effects. Both methods assume the existence of out-of-body contacts between the healer and the patient. Except for a temporary improvement in the patient's psyche, the therapeutic effect of these methods has not been proven. ${ }^{3}$ Despite the shift in political ideology and the rejection of the Soviet model guided by dialectic materialism, officials showed a dismissive attitude toward psychotronics. Further, the broader social trends resulted in technoscientization of biomedical knowledge, which can be characterized by the fact that 'interventions for treatment and enhancement are progressively more reliant on sciences and technologies, are conceived in those very terms, and are ever more promptly applied' (Clarke et al. 2010: 2). Consequently, the redefinition of biomedical identity eventuates in eliminated possibilities of the psy-

4 The full statement can be download from: http://www.lkcr.cz/stanoviska-vr-clk-417.html. [2019-01-30] 
chotronics community to provide verifiable scientific explanations and integrate psychotronics into the models of mainstream science.

\section{Conclusion}

Except for a few cases, the situation regarding the phenomenon of alternative therapies in the socialist period remains deeply unexplored. The findings of this paper suggest that, despite the prevalent rationalist view during the socialist period and the tendency to promote biomedicine as the only legitimate and superior healthcare practice, the conditions for the development of pluralism in medical healthcare were nevertheless created. In turn, from the perspective of our investigation, the case of psychotronics, whose medical application has developed exclusively in former Czechoslovakia, reveals that healthcare during the socialist period was a heterogeneous field, with its shifting boundaries of science and the changing character of the medical environment. In order to achieve wider acceptance, psychotronics made systematic efforts to move to the margins of science. According to available information, psychotronics, interestingly, not only became conditionally accepted, but, moreover, contested paradigms of the scientific world. This means that, despite the widespread doctrine of materialism during the socialist period, psychotronics gained access to state benefits because the representatives of medicine and science were incapable, at that time, of reaching a consensus on what constituted mainstream medicine and where to set the boundaries between different therapeutic concepts. Conversely, later on, after dramatic social changes and the development of pluralism, even in the area of healthcare, psychotronics lost its acquired status and the possibility to make further progress. Regarding healthcare, and science in general, as part of the cultural and social world, which is in a constant process of reinterpretation, rather than thinking about it as a monolithic object which becomes increasingly perfect, enables us to understand the shifting relationship between psychotronics and mainstream medicine over time in a wider context. Thus, considering the specific features of healthcare as a historically transforming product, which underwent different development stages, reveals how scientific objectification fluctuates, or at least is negotiable, under the influence of social circumstances and how the notion of what is considered as alternative/mainstream is constructed and shaped. To conclude, the alternative therapy-biomedicine opposition does not necessarily relate to different epistemological bases (as is often proclaimed in various statements regarding CAM), but to the dynamic and evolving nature of social processes.

October 2019 


\section{Bibliography}

Baer, Hans A. - Singer, Merrill - Susser, Ida. 2003. Medical Anthropology and the World Systems. Westport: Praeger Publishers.

Belko, Dušan. 2000. Psychotronická problematika: história a súčasnost'. [Psychotronics Issues: History and Present.] Psychotronica Slovaca 2000: 5-18.

Berger, Arthur S. - Berger, Joyce. 1991. The Encyclopedia of Parapsychology and Psychical Research. New York: Paragon House Publishers.

Brodwin, Paul. 1996. Medicine and Morality in Haiti. Cambridge UK: Cambridge University Press.

Brosnan, Caragh - Vuolanto, Pia - Brodin Danell, Jenny-Ann. 2018. Introduction: Reconceptualising Complementary and Alternative Medicine as Knowledge Production and Social Transformation. In: Complementary and Alternative Medicine Knowledge Production and Social Transformation. Palgrave Macmillan: 1-30.

Cant, Sarah - Sharma, Ursula. 1999. A New Medical Pluralism? Alternative Medicine, Doctors, Patients and the State. London: Routledge.

Clarke, Adele E. - Shim, Janet K. - Mamo, Laura - Fosket, Jennifer R. - Fishman, Janet K. 2010. Biomedicalization. In: Biomedicalization: Technoscience, Health and Illness in the U.S. Durham: Duke University Press.

Hamilton, Thomas C. 1977. Soviet and East European Parapsychology Research (report). [2019-01-30] Retrieved from Central Intelligence Agency Website: https://www.cia.gov/library/readingroom/document/nsa-rdp96x00790r000100010041-2

Horváthová, Emília. 1987. K vývoju etnomedicíny na Slovensku. [Development of ethnomedicine in Slovakia.] In: Studia Academica Slovaca 16. Bratislava: Alfa: 151-166.

Hsu, Elisabeth. 2008. "Medical Pluralism." In: International Encyclopedia of Public Health: f-O. Vol. 4. Amsterdam: Elsevier: 316-321.

Kleinman, Arthur. 1980. Patients and Healers in the Context of Culture: An Exploration of the Borderland between Anthropology, Medicine, and Psychiatry. Berkeley: University of California Press.

Klepal, Jaroslav - Stöckelová, Tereza. 2018. Exploring Biomedicalization Through Complementary and Alternative Medicine in a Postsocialist Context. Medical Anthropology 37, 5: 412-425.

Kováč, Peter. 2008. Činnost' l'udových liečitel'ov a trestná zodpovednost'. [The activity of folk healers and criminal responsibility.] Fustičná Revue 60: 1181-1187.

Kř́žzová, Eva. 2015. Alternationí medicína v České republice. [Alternative medicine in Czech republic.] Praha: Univerzita Karlova v Praze. 
Johannessen, Helle - Lázár, Imre. 2006. Multiple medical realities. Patients and Healers in Biomedical, Alternative and Traditional Medicine. New York: Berghahn.

Last, Murray. 1996. "Professionalization of indigenous healers." In: Medical Anthropology. Contemporary Theory and Method 2nd Edition. New York: Praeger: 374-395.

Leslie, Charles (ed.). 1976. Asian Medical Systems: A Comparative Study. Berkeley: University of California Press.

Leslie, Charles. 1980. Medical Pluralism in World Perspective [1]. Social Science and Medicine 14, 4: 191-195.

Maire, Louis F. - Lamothe, J. D. 1975. Soviet and Czechoslovakian Parapsychological Research (report). Medical Intelligence and Information Agency.

Michaels, Paula A. 2003. Curative Powers: Medicine and Empire in Stalin's Central Asia. Pittsburgh: University of Pittsburgh Press.

Nedelcheva, Anely - Draganov, Stefan. 2014. Bulgarian Medical Ethnobotany: The Power of Plants in Pragmatic and Poetic Frames. In: Ethnobotany and Biocultural Diversities in the Balkans. New York: Springer: 45-66.

Ong, Chi-Keong - Hog, Erling - Bodeker, Gerard - Burford, Gemma. 2005. Regional Overview: European Region. In: WHO Global Atlas of Traditional, Complementary and Alternative Medicine. Kobe: WHO: 109-116.

Penkala-Gawecka, Danuta. 1995. Folk and complementary medicine in polish ethnological investigations. Lud 79: 121-141.

Rao, Ramakrishna K. 2010. Yoga and parapsychology. Delhi: Motilal Banarsidass.

Rosinský, Teodor. 1991. Bioterapia príručka pre liečitelov. [Biotherapy guide for healers.] Bratislava: Flash Channel.

Rosinský, Teodor. 2012. Psychotronický výskum - realita a perspektívy. [Psychotronics Research - Reality and Perspectives.] Psychotronica Slovaca 2012: 2-3.

Rosinský, Teodor - Synčák, Norbert. 2008. Perspektívy psychotronicky. [Perspectives of Psychotronics.] Bratislava: CAD Press.

Ross, Anamaria I. 2012. The Anthropology of Alternative Medicine. London: Berg.

Saks, Mike. 2005. Political and historical perspectives. In: Perspectives on Complementary and Alternative Medicine. Abingdon: Routledge: 53-73.

Sharma, Ursula. 1996. Using complementary therapies: A challenge to orthodox medicine? In: Modern medicine: Lay perspectives and experiences. London: UCL Press: 230-255. 
Solár, Gustáv. 2013. Introduction to natural medicine. Acupuncture and Natural Medicine 2013, 1: 4-9.

Souček, Ivan - Hofreiter, Roman. 2017. Komplementárna a alternatívna medicína na Slovensku z pohladu sociálnych vied. [Complementary and alternative medicine in Slovakia from the social science perspective.] Sociológia 49, 4: 427-450.

Spiegel, David - Stroud, Penny - Fyfe, Ann. 1998. Complementary medicine. Western fournal of Medicine 168, 4: 241-247.

Stepan, Jan. 1985. Traditional and Alternative Systems of Medicine: a Comparative Review of Legislation. International Digest of Health Legislation 36, 2: 283-341.

Stöckelová, Tereza - Klepal, Jaroslav. 2018. Evidence-Based Alternative, 'Slanted Eyes' and Electric Circuits: Doing Chinese Medicine in the Post/Socialist Czech Republic. In: Complementary and Alternative Medicine Knowledge Production and Social Transformation. Palgrave Macmillan: 33-58.

Sirious, Fuschia M. - Gick, Mary L. 2002. An investigation of the health beliefs and motivations of complementary medicine clients. Social Science and Medicine 55, 6: 1025-1037.

Targ, Russell. 1983. International Conference on Psychotronic Research: June 5-10, 1983.

Telec, Ivo. 2017. Akupunktura jako problém zdravotnického práva. [Acupuncture as a problem of health law.] Zdravotnické právo a bioetika. [2019-01-30] Retrieved from: https://zdravotnickepravo.info/akupunktura-jako-problem-zdravotnickeho-prava/. 